\section{DETERMINATION OF STRUCTURAL, PHYSICAL, AND THERMAL PROPERTIES OF BIOCOMPOSITE THIN FILM FROM WASTE BANANA PEEL}

Nik Alnur Auli Nik Yusufa*, Mohammad Khairul Azhar Abdul Razabb, Mohamad Bashree Abu Bakara, Khor Jia Yena, Chee Wing Tunga, Ros Syazmini Mohd Ghanic, Mohd Nasha'ain Nordind

aAdvanced Materials Research Cluster, Faculty of Bioengineering and Technology, Universiti Malaysia Kelantan Jeli Campus, Locked Bag No. 100, 17600 Jeli, Kelantan, Malaysia

bSchool of Health Sciences, Universiti Sains Malaysia Health Campus, 16150 Kubang Kerian, Kelantan, Malaysia

cSchool of Engineering and Technology, University College of Technology Sarawak, 96000 Sibu, Sarawak, Malaysia

aAdvanced Materials Research Centre (AMREC), Lot 34, Jalan HiTech 2/3, Kulim Hi-Tech Park, 09000 Kulim, Kedah, Malaysia
Article history

Received

25 March 2018

Received in revised form

21 August 2018

Accepted

1 September 2018

Published online

15 December 2018

*Corresponding author alnurauli@umk.edu.my

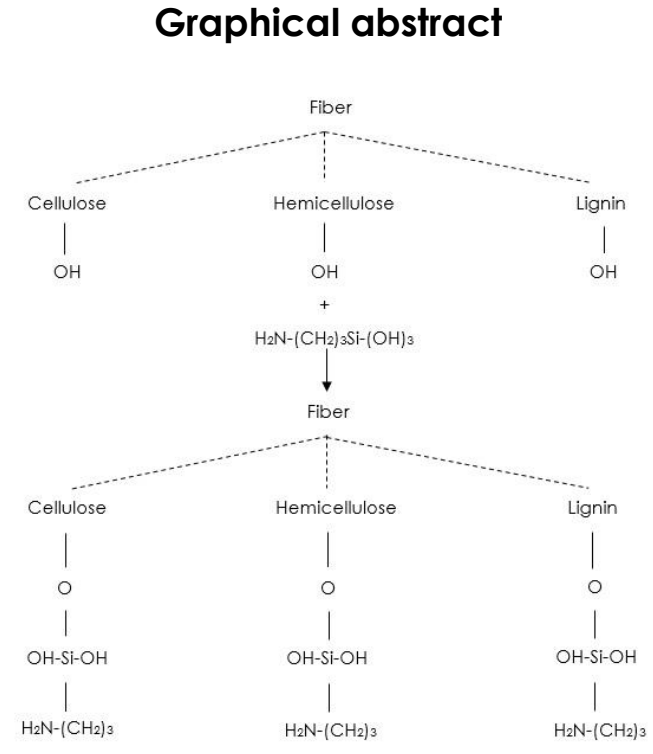

\begin{abstract}
This study summarizes the research on organic fillers, where eggshells were used as the reinforcement and banana peels as the matrix in the manufacturing of biocomposite thin film. Banana peel fibers exhibit a good characteristic of renewable material for the substitution of cement-based composites. However, biocomposite properties are limited by the poor adhesion between natural fiber interface and polymer matrix, which can be improved by chemical modification of fibers. In this research, banana peels were subjected to silane treatment. Biocomposite thin film manufacturing processes were carried out using blending and hand lay-up techniques with various concentrations of epoxy/waste banana peels/eggshell filler (EWE) ratios (EWE 0\%, EWE 5\%, and EWE 10\%). X-ray diffraction (XRD), Fourier transform infrared (FTIR), thermogravimetric analysis (TGA), and thickness swelling test were conducted on silane-treated and untreated banana peel biocomposite samples. In XRD analysis, it was found that EWE $10 \%$ sample had the highest crystallinity compared to EWE 0\% and EWE 5\%, and silane-treated samples had higher crystallinity than untreated samples. For FTIR test, lignin component was removed in silane treatment based on the changes of IR peak characteristic where the new bonds (-Si-O-C-, -Si-O-Si-, and -Si-C-) were found in treated samples. Besides, TGA results showed that the thermal stability of silane-treated samples was improved significantly with the increase of eggshell filler percentage, which was proven by the decrease in the decomposition stage. In thickness swelling test, the samples achieved higher swelling percentage as the percentage of eggshell filler increased. However, the decrease of $5-6 \%$ in thickness swelling of treated samples was possibly offset by the enhancement in fiber/matrix interfacial adhesion.
\end{abstract}

Keywords: Banana peel fibers, eggshells, silane treatment, X-ray diffraction, crystallinity 


\begin{abstract}
Abstrak
Kajian ini membentangkan ringkasan pengetahuan mengenai pengisi organik- kulit telur yang digunakan sebagai pengukuh dalam biokomposit filem nipis kulit pisang. Serat kulit telur merupakan bahan yang boleh diperbaharui dan boleh dijadikan pengganti komposit berasaskan simen. Walau bagaimanapun, sifat-sifat biokomposit adalah terhad oleh kelemahan lekatan semula jadi antara serat dengan matriks polimer. Namun, keadaan ini boleh diperbaiki dengan rawatan kimia pada permukaan serat. Dalam kajian ini, kulit pisang didedahkan kepada rawatan silana. Proses pembuatan biokomposit filem nipis dijalankan dengan pengadunan dan teknik bengkalai tangan diikuti dengan mencampurkan pengisi kulit telur dalam pelbagai nisbah (EWE 0\%, EWE 5\%, dan EWE 10\%). Pembelauan sinar-X (XRD), spektroskopi transformasi Fourier inframerah (FTIR), analisis termogravimetri (TGA), dan ujian pembengkakan ketebalan dijalankan ke atas sampel biokomposit yang telah dirawat dan tidak dirawat. Dalam ujian XRD, EWE 10\% didapati mempunyai tahap kehabluran yang paling tinggi berbanding dengan EWE 0\% dan EWE 5\%. Selain itu, sampel dirawat dengan silana serta penambahan kulit telur telah mencapai tahap kehabluran yang lebih tinggi berbanding dengan sampel yang tidak dirawat. Bagi ujian FTIR, komponen lignin telah disingkirkan dalam rawatan silana berdasarkan bukti sifat puncak inframerah yang berubah di mana ikatan baru (-Si-O-C-, -Si-O-Si-, dan -Si-C-) telah ditemui dalam sampel yang dirawat. Keputusan kajian TGA mendapati sampel dirawat silana telah menunjukkan kestabilan sifat haba yang sangat baik seiring dengan peningkatan peratus pengisi kulit telur di dalam sampel tersebut dengan bukti berkurangan pada peringkat penguraian. Bagi ujian pembengkakan ketebalan pula, pembengkakan ketebalan sampel meningkat seiring dengan peningkatan pengisi kulit telur. Namun, penurunan sebanyak 5-6\% bagi kajian pembengkakan ketebalan dalam sampel dirawat silana berkemungkinan disebabkan peningkatan lekatan antara fasa di antara serat dengan matriks polimer.

Kata kunci: Serat kulit pisang, kulit pisang, rawatan silana, pembelauan sinar$\mathrm{X}$, kehabluran
\end{abstract}

(c) 2019 Penerbit UTM Press. All rights reserved

\subsection{INTRODUCTION}

According to Nathalie and Martelli [1], biocomposite materials have gained attention due to both economic and ecological concern in the last decades. The impact of visible pollution has first driven the scientific and industrial communities to look further at biofragmentable and biodegradable materials to substitute for traditional petroleum-based non-biodegradable materials. Over the last few years, there has been an interesting development where polymer is added with organic fillers instead of inorganic fillers [2]. The cost of organic fillers is usually very low and they are also biodegradable. Moreover, organic fillers can also enhance some of the mechanical and thermomechanical properties in thermoplastic polymer [3].

Banana peel is a major byproduct and waste material rich in starch. In past research, researchers have focused their study on the utilization of waste banana peel as fiber reinforcement in polymer matrix. Yuvaraj and Jeyanthi [4] produced brake pads using banana peel powder and kenaf powder as the fiber or filler material. The results showed that the brake pads composite had relative compressive strength to withstand load application. Even though wear and morphological tests were not performed to predict its wear resistance, it was concluded that banana peel powder and kenaf powder could be exploited as a filler material for mass-scale fabrication of asbestos-free brake pad without any harmful effect.

The term filler refers to the dispersed phase of composite resins. A filler is able to increase the strength and characteristics that are necessary for a restorative material. Silane coating of fillers may increase resistance to hydrolytic degradation [5]. Organic fillers such as eggshell are biodegradable and originated from renewable sources, which ease the concern about their disposal problem.

Eggshell consists of $95 \%$ calcium carbonate $\left(\mathrm{CaCO}_{3}\right)$ as its main component and it is in the form of calcite. In $\mathrm{CaCO}_{3}$, calcite is the most stable component that forms elongated structures called columns, crystallite, or palisade [6]. Besides that, the remaining $5 \%$ of other inorganic materials in the eggshell are calcium phosphate, magnesium carbonate, and soluble and insoluble proteins. $\mathrm{CaCO}_{3}$ is the brittle white stuff that limestone, chalk, sea shells, coral, and pearls are made of [7]. Alternative use of eggshells as the components in 
structural materials will benefit in mitigating these challenges while meeting other societal needs [8].

Some researchers have shown that natural plant fiber can be modified to improve its properties. One of the approaches is to apply treatment on fiber. There are various types of fiber surface modifications such as mercerization, latex coating, gamma radiation treatment, silane treatment, isocyanate treatment, acetylation, and peroxide treatment [9]. These methods have been applied to reduce hydrophilicity and thus decrease the sorption characteristic of fiber. Different treatments will cause changes in physical and chemical modifications of fibers such as water sorption behavior. The effect of sorption on untreated and mechanically-treated samples was studied and investigated. As a result, a decrease was observed in the mechanical properties of fibers upon water sorption and then increased upon water desorption [10].

In this study, the main fiber constituents such as cellulose, hemicellulose, and lignin were separated from treated fibers. X-ray diffraction (XRD), Fourier transform infrared (FTIR), thermogravimetric analysis (TGA), and water absorption analysis of these constituents were carried out separately to develop a basic fundamental of the behavior of individual fiber constituent.

\subsection{METHODOLOGY}

\subsection{Materials}

The materials used in this study were banana peels, eggshells, glycerol, epoxy, (3-aminopropyl) trimethoxysilane, and acetone. Banana peels and eggshells were collected from small-medium industries (SMI). Banana peels were dried in an oven for $3 \mathrm{~h}$ to remove water content whereas eggshells were washed, dried, and blended into powder. A sieve was used to filter eggshell powder to obtain an average particle size of $75 \mu \mathrm{m}$.

\subsection{Methods}

Dried banana peels were sliced into smaller portions and boiled for $20 \mathrm{~min}$ to soften them. Water volume $(\mathrm{ml})$ and weight of banana peels (g) were in the ratio of $4: 1$. After 20 min, banana peels were blended with glycerol and eggshells for $10 \mathrm{~min}$. The amount of glycerol used was $15 \%(\mathrm{w} / \mathrm{w})$ of dried banana peels. Then, the blended mixture was boiled for $15 \mathrm{~min}$. Next, the boiled blended mixture was spread over a silkscreen using hand lay-up method to form a thin film. The thickness of thin film was in the range of 0.10 to $0.15 \mathrm{~mm}$. Later, the mixture on the silkscreen was placed and dried in an oven at $80^{\circ} \mathrm{C}$ for $3 \mathrm{~h}$. Lastly, the dried biocomposite thin film was coated with epoxy resin and compressed by a mould compressor.

The methods were repeated with different ratios of banana peels and eggshells. The biocomposite thin films were categorized into epoxy/waste banana peels/eggshell filler (EWE) with EWE 0\%, EWE 5\%, and EWE $10 \%$. The percentages and ratios of banana peels and eggshells used are shown in Table 1. Besides, the procedures were also repeated using silane-treated banana peels.

Table 1 Percentage of banana peels and eggshells

\begin{tabular}{cc}
\hline Banana peels (\%) & Eggshells (\%) \\
\hline 100 & 0 \\
95 & 5 \\
90 & 10 \\
\hline
\end{tabular}

2.3 Testing Methods of Structural, Physical, and Thermal Properties

\subsubsection{X-ray Diffraction}

The crystalline structures of thin-film samples were determined by XRD technique. XRD analysis was carried out using a Bruker D8 ADVANCE Powder XRD instrument with CUK-a radiation of $\lambda=1.5404 \mathrm{~nm}$ and the $X$-ray diffractometer was operated at a voltage of $40 \mathrm{kV}$ and a current of $30 \mathrm{~mA}$. XRD data were collected within the range of scattering angles (2 $\theta$ ) of 10 to $40^{\circ}$ at room temperature.

Crystallinity index (Crl) was calculated using the formula as stated in Equation 1:

$$
\mathrm{Crl}(\%)=\left[\left(I_{200}-I_{C r-n o n}\right) / I_{200}\right] \times 100
$$

where $I_{200}$ and $/$ cr-non are the maximum peak intensities of crystalline and amorphous regions, respectively.

\subsubsection{Fourier Transform Infrared}

For FTIR analysis, the specimens were tested by Shimadzu 8400 S FTIR spectrometer at a resolution of 4 $\mathrm{cm}^{-1}$ (40 scans). The information on the blend, composite composition, and polymer-polymer interaction were determined and presented in the results.

\subsubsection{Thermogravimetric Analysis}

TG/DTG curves were obtained using Seiko EXSTAR 6000 TG/DTA 6300 thermal analyzer. Approximately $10.2 \mathrm{mg}$ of samples were placed on an aluminum pan for testing. This test was carried out from 30 to $900{ }^{\circ} \mathrm{C}$ in dynamic nitrogen atmosphere with the flow rate of $10 \mathrm{ml} / \mathrm{min}$ and heating rate of $10^{\circ} \mathrm{C} / \mathrm{min}$.

\subsubsection{Water Absorption and Thickness Swelling Analysis}

Water absorption test was conducted in accordance with ASTM D570-98. The samples for each ratio were cut into the dimensions of $24 \times 10 \mathrm{~mm}^{2}$. Thin-film samples were dried in an oven at $80^{\circ} \mathrm{C}$ prior to measurement. Water uptake was measured at $120 \mathrm{~h}$ intervals until weight stabilization was obtained. 
Then, water absorption was calculated using weight difference while swelling index (SI) was calculated using the following equation:

$$
S I=\left[\left(W_{f}-W_{i}\right) / W_{i}\right] \times 100 \%
$$

where $\mathrm{SI}$ is the water absorption of specimen after $\mathrm{N}$ hours of water soaking (\%), $W_{f}$ is the final weight of specimen after $N$ hours of water soaking $(g)$, and $W_{i}$ is the initial weight of specimen before $\mathrm{N}$ hours of water soaking (g).

\subsection{RESULTS AND DISCUSSION}

\subsection{Analysis of X-ray Diffraction}

XRD analysis has been done to compare the crystalline phase between untreated and treated biocomposite thin films. The patterns exhibited an intense peak at around $2 \theta=30^{\circ}\left(I_{200}\right)$ for both treated and untreated samples. This peak represents the crystallinity region in samples. On the other hand, the amorphous region of samples is represented by the valley between the peaks, which is shown in Icr-non at around $2 \theta=28^{\circ}$. After the silane treatment of biocomposite thin film, it could be observed that the peak at $2 \theta$ position around $30^{\circ}$ became narrower and more intense compared to untreated samples. This situation indicates a higher degree of crystallinity in treated samples [11].

Based on Table 2, the calculation of $\mathrm{Crl}$ showed that treated samples had higher $\mathrm{Cr}$ values compared to untreated samples. For example, treated EWE $10 \%$ (23.2\%) had higher degree of crystallinity than untreated EWE 10\% (17.8\%). Based on the study by Jonoobi et al. [12], lignin and hemicelluloses in fibers were removed during fiber treatment process and therefore resulted in the increase of Crl.

Based on Figure 1 and 2, both untreated and silane treated samples showed that the shape of $2 \theta$ XRD patterns was almost similar despite different percentages of reinforced eggshells. The crystallization degree of treated specimens was lower than untreated specimens as the surface of banana peels was modified by silane coupling agent. The crystal cell structure of cellulose for modified banana peels was distinguishable compared to unmodified banana peels [13]. This situation shows that with the modification of silane treatment on banana peels, the crystallization degree of treated biocomposite samples increases compared to untreated samples.

In the intracomparison of untreated EWE 0\%, EWE $5 \%$, and EWE 10\%, it was found that EWE 10\% had higher crystallinity (17.8\%) and contained higher concentration of $\mathrm{CaCO}_{3}$ (JCPDS card 00-003-0569) [14] compared to others. This phenomenon occurred in a similar situation in the intracomparison of silanetreated EWE 0\%, EWE 5\%, and EWE 10\%, where treated EWE 10\% showed the highest crystallinity (23.2\%) and it contained the highest concentration of calcite among them. All specimens of banana peels reinforced with eggshells thin film are preferably considered as amorphous structure as banana peels functioned as a matrix in the fabrication of biocomposite thin film.

Nevertheless, it was clearly shown that the sharp peaks at $2 \theta=42^{\circ}$ that represent $\mathrm{CaCO}_{3}$ only appeared on both graphs of treated and untreated EWE 5\% and EWE $10 \%$ but not EWE $0 \%$ due to the addition of eggshells as a reinforced material in the thin film. However, it has been reported that calcite might not significantly influence the crystallinity of polymer matrix [15]. Besides, eggshells were not modified in this research, thus untreated $\mathrm{CaCO}_{3}$ particles did not have any effect on the crystallinity of the samples [16].

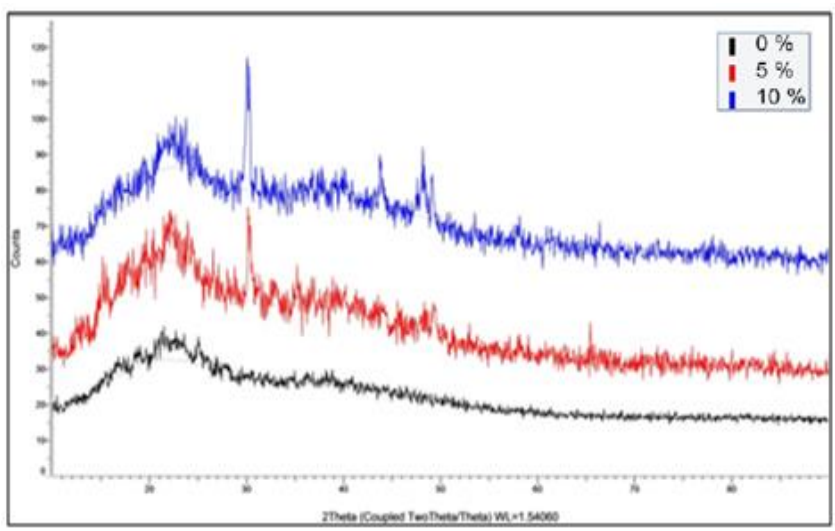

Figure 1 XRD patterns of untreated samples

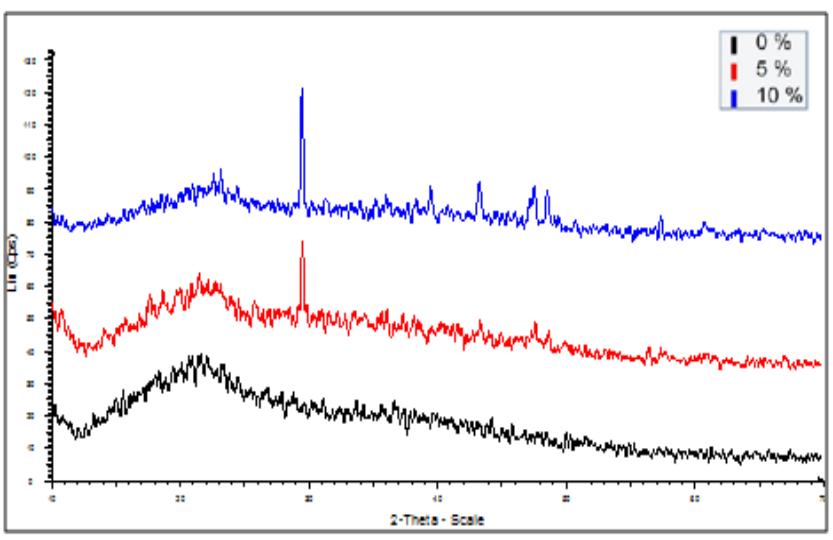

Figure 2 XRD patterns of treated samples

Table 2 Comparisons of crystallinity index of untreated and treated samples

\begin{tabular}{ccc}
\hline \multirow{2}{*}{ Samples } & \multicolumn{2}{c}{ Crystallinity Index (\%) } \\
\cline { 2 - 3 } & Untreated & Treated \\
\hline EWE 0\% & 16.9 & 20.2 \\
EWE 5\% & 17.1 & 21.7 \\
EWE 10\% & 17.8 & 23.2 \\
\hline
\end{tabular}




\subsection{Functional Group Identification by FTIR}

FTIR characterization is able to identify functional groups and measure the transmittance of banana peel biocomposite thin film of each sample [17]. Figure 3, 4, and 5 show the comparison of FTIR spectra between untreated and treated EWE 0\%, EWE 5\%, and EWE 10\%. The comparison of $\mathrm{OH}$ stretch absorbance is presented in Table 3 while the wavelength of peaks used for FTIR analysis and its corresponding functional groups are listed in Table 4.

It can be seen some peaks were exist and represents the functional groups present in the samples. The first observation of the IR spectra shows a strong absorption band at $3282 \mathrm{~cm}^{-1}$, which is assigned to hydroxyl group $\mathrm{O}-\mathrm{H}$ and amine $\mathrm{N}-\mathrm{H}$ symmetrical stretching vibrations. This is due to the presence of hydroxyl group, where the glycerol used in the experiment has three hydroxyl functional groups that are responsible for its solubility in water $[18,19]$.

The second observation focuses on the absorption band at $2922 \mathrm{~cm}^{-1}$ from the symmetric hydrocarbon $\mathrm{C}-\mathrm{H}$ stretching absorption band of $\mathrm{CH}$, $\mathrm{CH}_{2}$, and $\mathrm{CH}_{3}$. The $\mathrm{C}-\mathrm{H}$ stretching mode represents the aliphatic nature of banana peels [20]. The absorbance at $1730 \mathrm{~cm}^{-1}$ corresponds to carbonyl $\mathrm{C}=\mathrm{O}$ stretching vibration. This phenomenon represents the linkage of ester group in hemicelluloses or carboxylic acid in lignin [10]. A sharp peak at $1606 \mathrm{~cm}^{-1}$ is assigned to the characteristics of $\mathrm{C}=\mathrm{C}$ in aromatic rings due to the stretching of aromatic ring of lignin [21].

The peak at $1511 \mathrm{~cm}^{-1}$ corresponds to $\mathrm{CH}_{2}$ bending in lignin while the peak at $1374 \mathrm{~cm}^{-1}$ is due to $\mathrm{O}-\mathrm{H}$ in-plane bending. Meanwhile, the shift at 1029 $\mathrm{cm}^{-1}$ is assigned to C-O carboxyl band, which indicates the stretching of acetyl in lignin [19]. Some similar peaks were obtained and observed in previous studies by Lai et al. [22] and Khormaei et al. [23]. Lastly, the small sharp peak at $900 \mathrm{~cm}^{-1}$ was observed and assigned to a $\beta$-glycosidic linkage between sugar units in cellulose and hemicelluloses [10].

Referring to Table 3, for treated samples, the absorbance unit of hydroxyl absorption peaks for treated EWE 0\% was higher than untreated EWE 0\% due to the efficiency of silane agent [9]. With the addition of eggshell filler in composite, the absorbance value of treated samples was lower than untreated samples at the same constituent. Even the absorbance index of treated EWE $10 \%$ was ultimately lower than untreated EWE 10\%. This situation might be due to the addition of fillers in composites where fillers will absorb a considerable amount of hydroxyl that appears after silane treatment is applied on fibers [21].

A well-defined peak at $1200 \mathrm{~cm}^{-1}$ is assigned to -Si$\mathrm{C}$-Si- bond and this represents the reaction between cellulose of banana peels and hydrolyzed silane. The characteristic band at $778 \mathrm{~cm}^{-1}$ is attributed to $-\mathrm{Si}-\mathrm{C}$ symmetrical stretching while the band at $710 \mathrm{~cm}^{-1}$ corresponds to -Si-O-Si- symmetric stretching. Moreover, the treated samples showed a slightly weak absorption peak of carbonyl group at $1730 \mathrm{~cm}^{-}$ 1. Next, the decrease in the band splitting of $\mathrm{C}-\mathrm{H}$ bond stretching vibrations range of methyl and methylene groups indicates the removal of lignin-like structure [21].

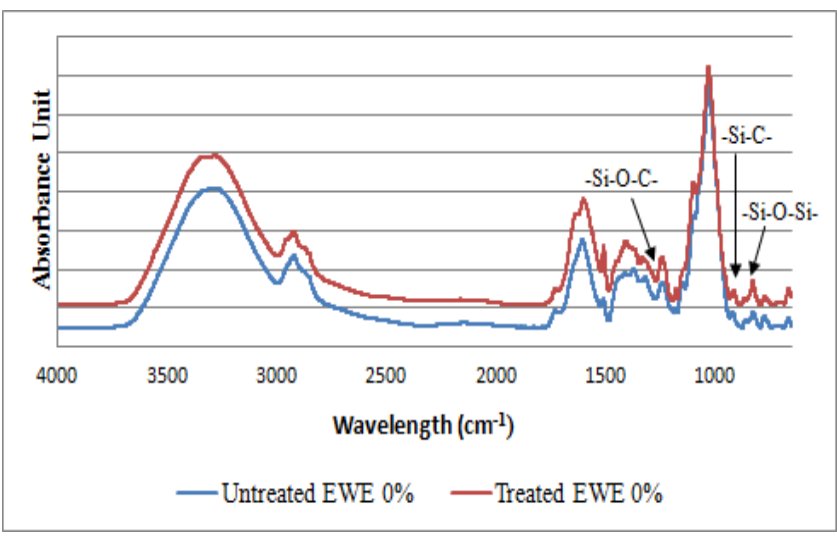

Figure 3 Comparisons of FTIR spectra between untreated EWE $0 \%$ and treated EWE 0\%

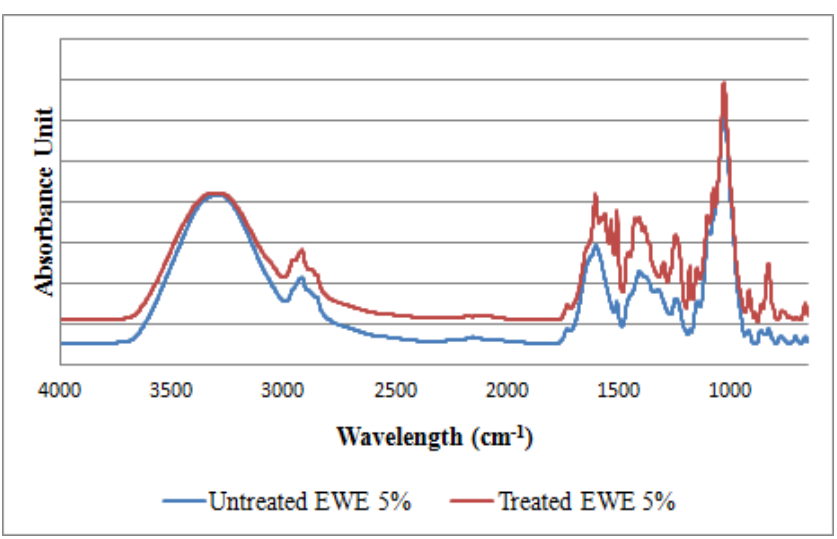

Figure 4 Comparisons of FTIR spectra between untreated EWE 5\% and treated EWE 5\%

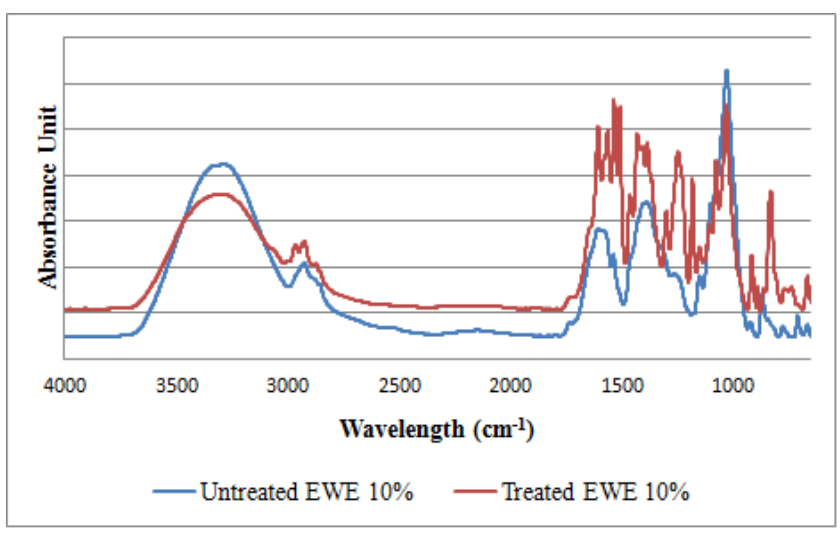

Figure 5 Comparisons of FTIR spectra between untreated EWE $10 \%$ and treated EWE 10\% 
Table 3 Comparisons of $\mathrm{OH}$ absorbance unit of untreated and treated samples

\begin{tabular}{ccc}
\hline \multirow{2}{*}{ Samples } & \multicolumn{2}{c}{ Absorbance unit of OH stretch } \\
\cline { 2 - 3 } & Untreated & Treated \\
\hline EWE 0\% & 0.17 & 0.20 \\
EWE 5\% & 0.18 & 0.16 \\
EWE 10\% & 0.19 & 0.13 \\
\hline
\end{tabular}

Table 4 Wavelength of peaks used for FTIR analysis and its corresponding functional groups $[24,13,9,25]$

\begin{tabular}{cl}
\hline $\begin{array}{c}\text { Characteristics } \\
\text { Absorption(s) } \\
\left(\mathbf{c m}^{-1}\right)\end{array}$ & \multicolumn{1}{c}{ Functional Groups } \\
\hline $3550-3200$ & O-H stretch \\
$2950-2850$ & C-H stretch \\
$1750-1735$ & C=O stretching of carboxylic acid or \\
& ester (lignin) \\
$1700-1500$ & C=C stretching of aromatic ring \\
& (lignin) \\
$1470-1350$ & CH H $_{2}$ symetrical bending (lignin) \\
$1430-1330$ & -OH bending \\
$1250-970$ & C-O stretching of acetyl (lignin) \\
$1000-970$ & B-glycosidic linkage \\
$1260-1000$ & -Si-O-C- stretching \\
$800-780$ & -Si-C- symmetric stretching \\
$720-700$ & -Si-O-Si- symmetric stretching \\
\hline
\end{tabular}

\subsection{Thermogravimetric Analysis}

TGA analysis was carried out to determine the silane treatment effects on thermal properties of biocomposite samples. [26]. TG/DTA curves are presented for untreated (Figure 6, 8, and 10) and treated (Figure 7, 9, and 11) samples.

In the first step of degradation, the observation showed a weight loss related to desorption of water of polysaccharide structure. According to Guimaraes et al. [27], the total elimination of water in fibers was quite difficult since fibers were hydrophilic in nature even though the fibers were dried before the experiment. The hydrophilic nature would then reduce the interfacial bonding between fibers and increase its moisture absorption after it was imparted by hydroxyl groups of cellulose in those fibers [28].

The second phase of degradation is related to the decomposition of hemicellulose content present in fibers. It has been reported that the decomposition of hemicelluloses was within the temperature range of 180 and $350{ }^{\circ} \mathrm{C}$ [29]. Hemicellulose will degrade faster than other chemical components in fibers such as cellulose and lignin. This is because hemicellulose consists of acetyl groups that may be responsible to lower its thermal stability. Thus, hemicelluloses will undergo cellular breakdown as temperature increases.

In the previous stage, a small amount of amorphous cellulose degraded, thus the third stage involved the degradation of crystalline cellulose. In fact, cellulose is more thermally stable than hemicellulose due to its crystalline nature, where it bonds to form microfibril structure by hydrogen bonding [30]. Therefore, when the temperature was greater than $300{ }^{\circ} \mathrm{C}$, the samples showed major weight loss (37\% to $50 \%$ ) due to the decomposition of cellulose and lignin.

The decomposition of lignin occurred slowly and under the temperature range up to $850{ }^{\circ} \mathrm{C}$. This is because lignin consists of heavy cross-linked molecules besides polysaccharides, thus making it hard to decompose under thermal decomposition. Therefore, lignin is considered as the most difficult component to decompose compared to organic components due to its slow decomposition [31].

A dry eggshell has approximately $94 \%$ of $\mathrm{CaCO}_{3}$ by mass [32]. The addition of $\mathrm{CaCO}_{3}$ in the composite decreases the crystalline regions of composite as the bonding energy between polymer chains is reduced by $\mathrm{CaCO}_{3}$ and finally decreases its melting point. Hence, the melting point is lower as a higher amount of $\mathrm{CaCO}_{3}$ is added to the composite.

Generally, the number of decomposition peaks for both treated and untreated EWE 0\% (Figures 6 and 7) is less than EWE 5\% (Figures 8 and 9) and EWE $10 \%$ (Figures 10 and 11). This is because the thermal stability of specimen is affected by the percentage of banana peel fibers. Greater thermal stability is achieved with a higher percentage of banana peel fibers in the sample, therefore less thermal changes will occur in the test [33]. This situation will lead to low thermal conductivity because fibers contain vacant structures [34].

This situation shows that silane treatment is incapable of eliminating hemicelluloses from fibers. In fact, silane molecules formed couplings with lignin and hemicellulose constituents of fibers instead of eliminating them from the fibers. A silane coupling agent acts as a protective covering layer on fiber surface to protect the fiber from thermal decomposition at higher temperature and thus, the breakdown of fiber molecular structure is prevented [35].

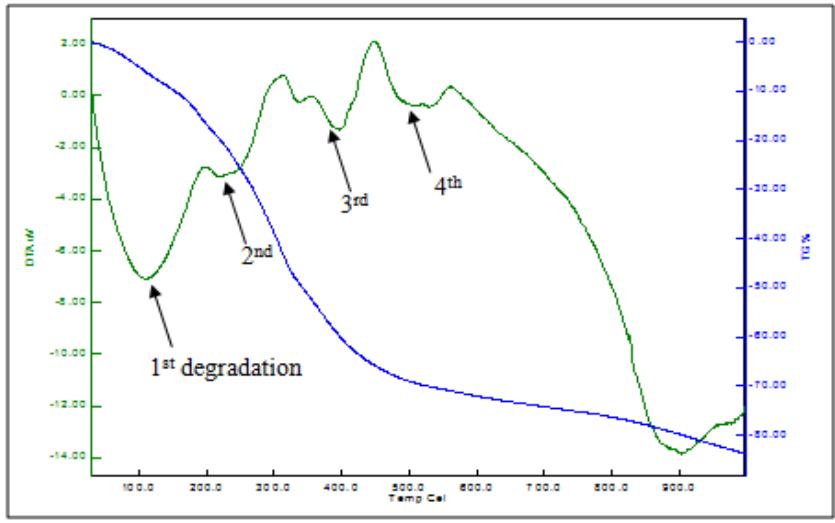

Figure 6 TG/DTA curves of untreated EWE 0\% 


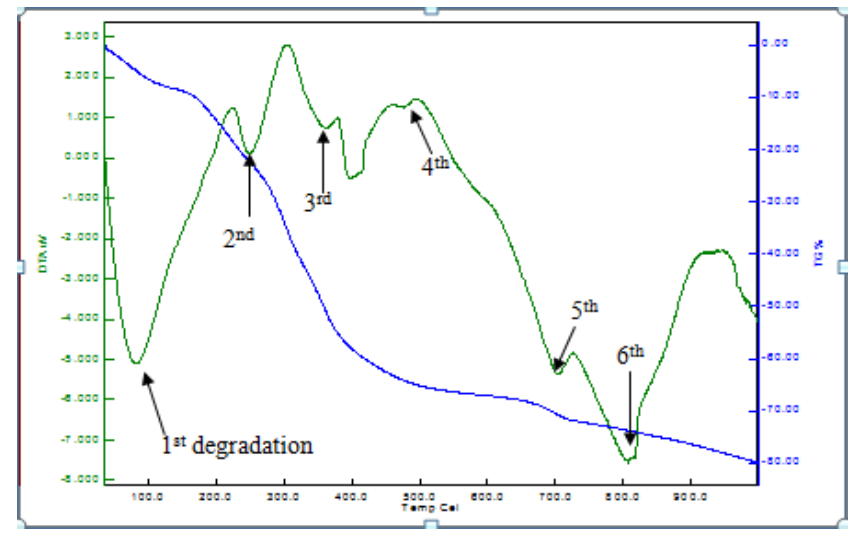

Figure 7 TG/DTA curves of treated EWE 0\%

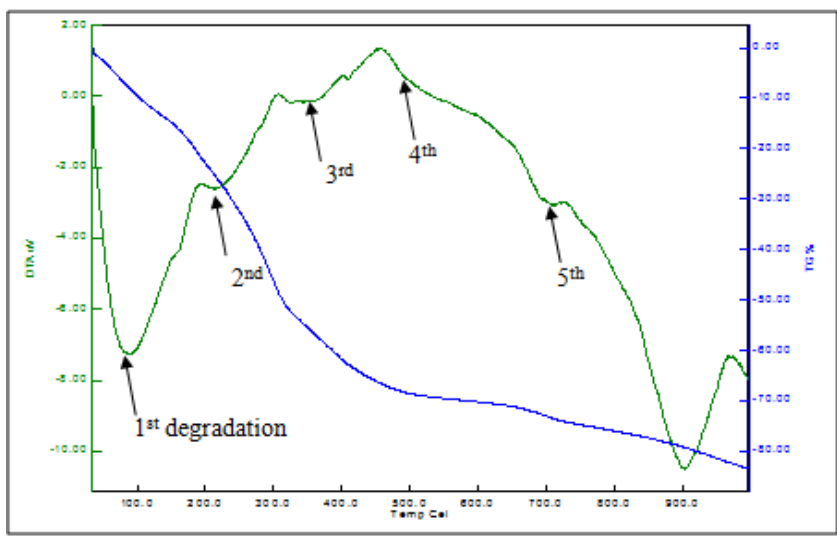

Figure 8 TG/DTA curves of untreated EWE 5\%

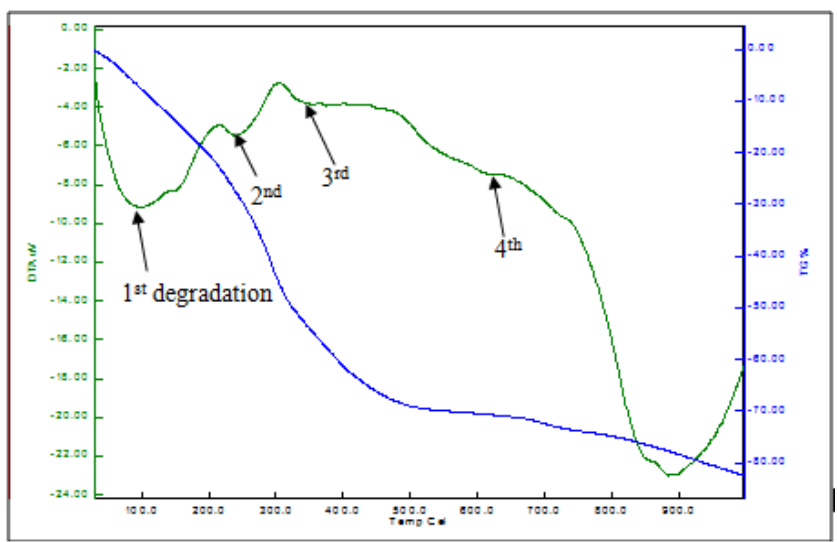

Figure 9 TG/DTA curves of treated EWE 5\%

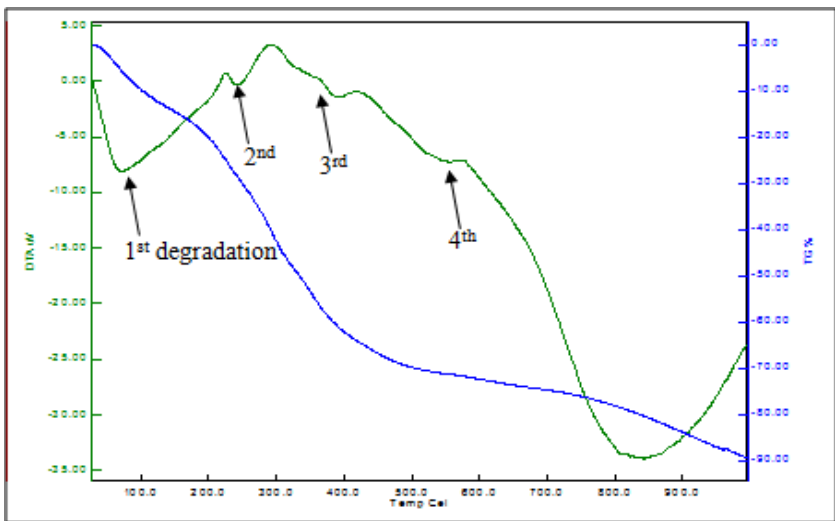

Figure 10 TG/DTA curves of untreated EWE 10\%

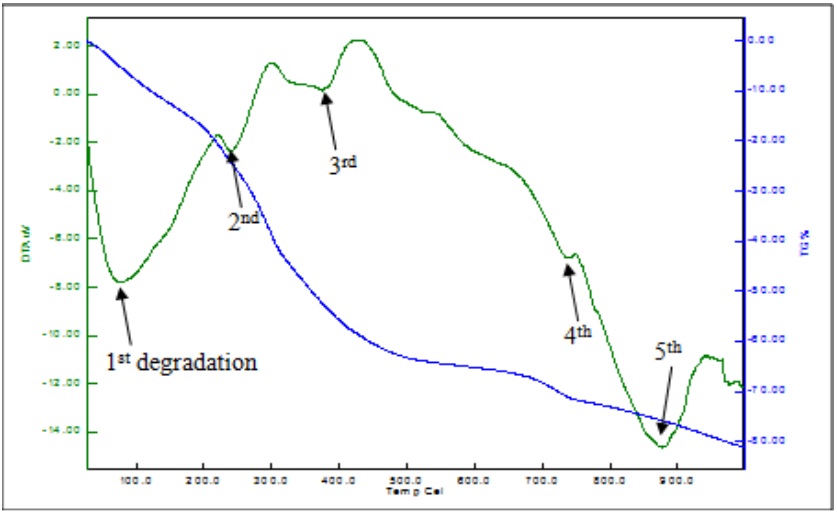

Figure 11 TG/DTA curves of treated EWE 10\%

\subsection{Water Absorption and Thickness Swelling Characteristics}

Figures 12 and 13 illustrate the thickness swelling behavior of silane-treated and untreated samples at different relative ratios of eggshell reinforcement. A comparison of thickness swelling percentage is concluded and tabulated in Table 5.

At the initial stage of absorption process, both figures showed that the thickness swelling increased linearly, then the increasing rates slowed down, and it finally reached water uptake at equilibrium. Among the three ratios, EWE 10\% had the highest moisture absorption, followed by EWE $5 \%$ and EWE $0 \%$. This is due to the addition of eggshells in EWE $10 \%$ and EWE $5 \%$ composites [36].

As reported by Abdel-Salam et al. [2], water absorption of composite increased as the amount of filler $\left(\mathrm{CaCO}_{3}\right)$ added increased. This situation may be because $\mathrm{CaCO}_{3}$ contains hydrophilic sites and thus it is expected that moisture absorption in composite increases [37]. This situation can be explained by the work of Santos et al. [36], where the addition of filler in composite significantly increased its water uptake due to the presence of filler particles and porosity aggregates in the microstructure of composite, even though the adsorption of water on the filler surface has not been removed. 
In the comparison of silane-treated and untreated samples with similar compositions of eggshell filler, the thickness swelling in treated samples was lower than that of untreated samples. For instance, untreated EWE $10 \%$ had $12 \%$ thickness swelling and the value dropped to $7 \%$ after silane treatment due to lower water absorption in treated samples. According to Arsène et al. [38], silanes in aqueous media are reactive molecules that will transform into dimers or oligomers by the condensation of silanol. Hence, silanes commonly exhibit greater repellent effect and are used as commercial water repellents. Additionally, silane treatment can decrease the hydrophilicity of fiber by decreasing the hydroxyl groups in fibers [39].

Nevertheless, Arsène et al. [38] also reported that silane was grafted onto the fiber surface to form a network of polysiloxane molecule. Banana fibers swelled as the morphology of fibers was modified and the porosity and dimensions of fibers increased at the same time. Thus, water absorption decreased with the addition of silane in the treatment solution.

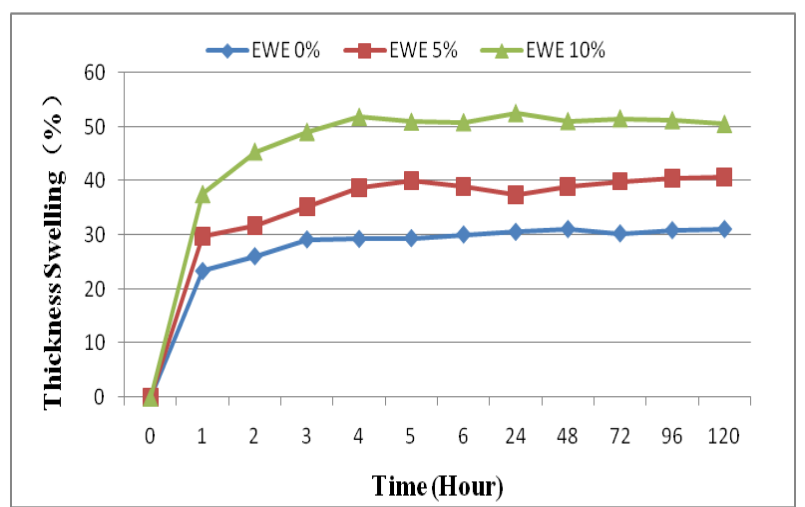

Figure 12 Thickness swelling of untreated samples

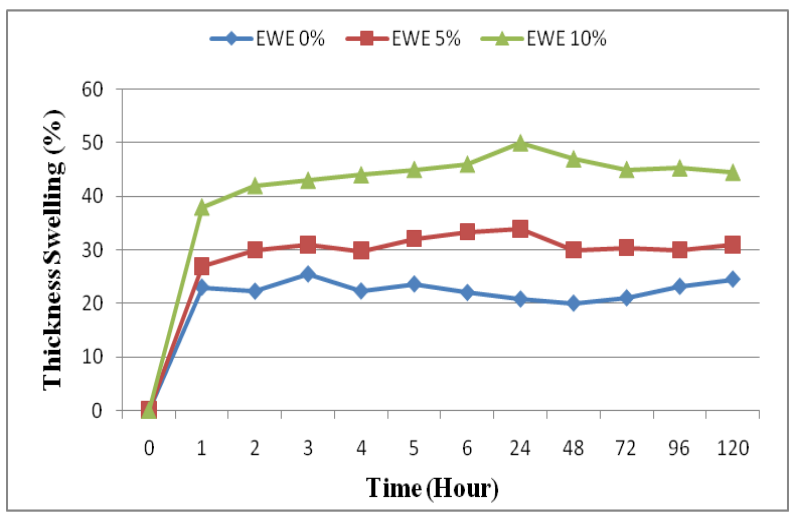

Figure 13 Thickness swelling of treated samples
Table 5 Thickness swelling percentages of treated and untreated samples

\begin{tabular}{ccc}
\hline \multirow{2}{*}{ Samples } & \multicolumn{2}{c}{ Thickness Swelling (\%) } \\
\cline { 2 - 3 } & Untreated & Treated \\
\hline EWE 0\% & 8 & 2 \\
EWE 5\% & 10 & 4 \\
EWE 10\% & 12 & 7 \\
\hline
\end{tabular}

\subsection{CONCLUSION}

In this research, biocomposite thin film was successfully produced from waste banana peels reinforced with eggshell filler and laminated with epoxy resin. Some portions of banana peels were treated with silane as the coupling agent in order to determine the effect of silane treatment on fiber properties. FTIR analysis indicated the presence of bonds in silane-treated samples compared to untreated samples. These new bonds formed as a result of the reaction between hydrolyzed silane agent and banana peel fibers. The intensity of $\mathrm{OH}$ absorption peaks in the treated samples was higher than untreated samples. However, the intensity of treated samples decreased as the percentage of eggshell fillers in the composite increased. For XRD results, the treated samples had high $\mathrm{Crl}$ than untreated samples and $\mathrm{Crl}$ increased as the eggshell percentage increased. Thus, treated EWE 10\% had the highest crystallinity among the samples due to the removal of lignin and hemicelluloses in fibers during silane treatment and it contained the highest percentage of eggshell filler. On the other hand, silane treatment resulted in the decrease of water absorption and thickness swelling of the composites. Without eggshell filler, further reduction was observed. Silane treatment of banana peel fibers produced composite samples with greater hydrophobicity and less water absorption. For thermal properties, the weight loss of silane-treated samples was lower than untreated samples. The addition of silane coupling agent and eggshell filler increased the melting point of biocomposite samples and hence enhanced its thermal stability.

\section{Acknowledgement}

We acknowledge the support of the Research Acculturation Grant Scheme (RAGS) awarded by the Ministry of Higher Education (MOHE) via Universiti Malaysia Kelantan under Grant Number: R/RAGS/A08.00/01030A/001/2015/000217. We also acknowledge the support of the Short-Term Research Grant (304/PPSK/6315174) awarded by Universiti Sains Malaysia. We express our appreciation to Dr. Muhammad Azwadi Sulaiman of the Faculty of Bioengineering and Technology, Universiti Malaysia Kelantan Jeli Campus for his advice on the results of XRD analysis. Our grateful thanks also go to Miss 
Madihan Yusof of the Faculty of Earth Science, Universiti Malaysia Kelantan Jeli Campus as a research assistant for this research project.

\section{References}

[1] Berezina, N., and Martelli, S. M. 2014. Bio-based Polymers and Materials. In Carol Lin and Rafael Luque (ed.). Renewable Resources for Biorefineries. London: Royal Society of Chemistry.

[2] Abdel-Salam, S. I., Begawy, E. S., Metwally, M. S., AbdelHakim, A. A., and Elshafie, E. S. 2011. Effect of Mineral Fillers on Rice Straw Fiber/High Density Polyethylene Composites. Nature and Science. 9(912): 116-124.

[3] La Mantia, F. P., Morreale, M., and Mohd Ishak, Z. A. 2005. Processing and Mechanical Properties of Organic Fillerpolypropylene Composites. Journal of Applied Polymer Science. 96(5): 1906-1913.

[4] Yuvaraj, L., and Jeyanthi, S. 2015. An Investigation on Chemical Treatment of Phenol Formaldehyde with Natural Fibers for Brake Pads. Journal of Chemical and Pharmaceutical Sciences. 7: 106-108.

[5] Deepthi. P. R. 2013. Filler in Composite Resin. Retrieved April 27, 2016, from Slide Share: www.slideshare.net/deepthipramachandran/fillers-incomposite-resins

[6] Nik Yusuf, N. A. A., Abdul Razab, M. K. A., Abdullah, N. H., Mohamed Noor, A., Yusoff, M., Ali, A., Mohd Kamal, N. A., and Nordin, M. N. A. 2016. Characterization of Bio-Polymer Composite Thin Film Based on Banana Peel and Egg Shell. International Journal of Current Science, Engineering \& Technology. 1(S1): 546-550

[7] Senese, F. 2010. General Chemistry Online. Retrieved April 25, 2016, from Antoine: http://antoine.frostburg.edu/chem/senese/101/consumer /faq/eggshell-compositions. html.

[8] Rahman, M. M., Netravali, A. N., Tiimob, B. J., and Rangari, V. K. 2014. Bioderived "Green" Composite from Soy Protein and Eggshell Nanopowder. ACS Sustainable Chemistry and Engineering. 2(10): 2329-2337.

[9] Sawpan, M. A., Pickering, K. L., and Fernyhough, A. 2011. Effect of Various Chemical Treatments on the Fibre Structure and Tensile Properties of Industrial Hemp Fibres. Composites Part A: Applied Science and Manufacturing. 42(8): 888-895

[10] Mohammed, L., Ansari, M. N. M., Pua, G., Jawaid, M., and Islam, M. S. 2015. A Review on Natural Fiber Reinforced Polymer Composite and Its Applications. International Journal of Polymer Science. 1-15.

[11] Razak, N. I. A., Ibrahim, N. A., Zainuddin, N., Rayung, M., and Saad, W. Z. 2014. The Influence of Chemical Surface Modification of Kenaf Fiber using Hydrogen Peroxide on the Mechanical Properties of Biodegradable Kenaf Fiber/Poly(Lactic Acid) Composites. Molecules. 19(3): 2957-2968.

[12] Jonoobi, M., Harun, J., Tahir, P. M., Zaini, L. H., SaifulAzry, S., and Makinejad, M. D. 2010. Characteristics of Nanofibers Extracted from Kenaf Core. BioResources. 5(4): 2556-2566.

[13] Miao, Y., and Zhang, G. 2011. Study about Characteristics of FTIR and XRD for Corn Stalk Surface with KH-560 Treatment. Energy Procedia. 16: 1135-1140.

[14] Nik Yusuf, N. A. A., Rosly, E. S., Mohamed, M., Abu Bakar, M. B., Yusoff, M., Sulaiman, M. A., and Ahmad, M. I. 2016. Waste Banana Peel and its Potentialization in Agricultural Applications: Morphology Overview. Materials Science Forum. 840: 394-398.

[15] Leong, Y. W., Abu Bakar, M. B., Ishak, Z. A. M., Ariffin, A., and Pukanszky, B. 2004. Comparison of the Mechanical Properties and Interfacial Interactions between Talc, Kaolin, and Calcium Carbonate Filled Polypropylene
Composites. Journal of Applied Polymer Science. 91(5): 3315-3326.

[16] Zuiderduin, W. C. J., Westzaan, C., Huétink, J., and Gaymans, R. J. 2002. Toughening of Polypropylene with Calcium Carbonate Particles. Polymer. 44(1): 261-275.

[17] Sutikno, S., Dharmaputera, N. M., and Rahayu, S. 2014. Fabrication and Characterization of Banana Flower Extract Anthocyanin-Based Organic Solar Cell. Journal of Advanced Agricultural Technologies. 1 (2): 89-93.

[18] Leroy G. Wadealcohol. 2016. In Encyclopaedia Britannica. Retrieved April 27, 2016 from https://global.britannica.com/science/alcohol.

[19] Stewart Fullard 2016. Monash Scientific Glass Blowing Services. Retrieved from http://www.monashscientific.com.au/Glycerol.htm.

[20] Kamsonlian, S., Suresh, S., Majumder, C. B., and Chand, S. 2011. Characterization of Banana and Orange Peels: Biosorption Mechanism. International Journal of Science Technology and Management. 2(4): 2229-6646.

[21] De Rosa, I. M., Kenny, J. M., Maniruzzaman, M., Moniruzzaman, M., Monti, M., Puglia, D., Sarasini, F. 2011. Effect of Chemical Treatments on the Mechanical and Thermal Behaviour of Okra (Abelmoschus Esculentus) Fibres. Composites Science and Technology. 71 (2): 246254.

[22] Lai, Y. L., Annadurai, G., Huang, F. C., and Lee, J. F. 2008. Biosorption of $\mathrm{Zn}$ (II) on the Different Ca-Alginate Beads from Aqueous Solution. Bioresource Technology. 99(14): 6480-6487.

[23] Khormaei, M., Nasernejad, B., Edrisi, M., and Eslamzadeh, T. 2007. Copper Biosorption from Aqueous Solutions by Sour Orange Residue. Journal of Hazardous Materials. 149(2): 269-274.

[24] Kabir, M. M., Wang, H., Lau, K. T., and Cardona, F. 2013. Effects of Chemical Treatments on Hemp Fibre Structure. Applied Surface Science. 276: 13-23.

[25] Grill, A. 2009. Porous pSiOCH Ultralow-k Dielectrics for Chip Interconnects Prepared by PECVD. Annual Review of Materials Research. 39: 49-69.

[26] Pereira, P. H. F., Carvalho Benini, K. C. C., Watashi, C. Y. Voorwald, H. J. C., and Cioffi, M. O. H. 2013. Characterization of High Density Polyethylene (HDPE) Reinforced with Banana Peel Fibers. BioResources. 8(2): 2351-2365.

[27] Guimarães, J. L., Frollini, E., da Silva, C. G., Wypych, F., and Satyanarayana, K. G. 2009. Characterization of Banana, Sugarcane Bagasse and Sponge Gourd Fibers of Brazil. Industrial Crops and Products. 30(3): 407-415.

[28] Pai, A. R., and Jagtap, R. N. 2015. Surface Morphology and Mechanical Properties of Some Unique Natural Fiber Reinforced Polymer Composites - A Review. Journal of Materials and Environmental Science. 6(4): 902-917.

[29] Liu, X., and Yu, W. 2006. Evaluating the Thermal Stability of High Performance Fibers by TGA. Journal of Applied Polymer Science. 99(3): 937-944.

[30] Gajiwala, H. M., and Zand, R. 2000. Synthesis and Characterization of Thermally Stable Polymers Containing Phenazine. Polymer: 41 (6): 2009-2015.

[31] Sevilla, M., and Fuertes, A. B. 2011. Sustainable Porous Carbons with a Superior Performance for $\mathrm{CO}_{2}$ Capture. Energy \& Environmental Science. 4(5): 1765-1771.

[32] Butcher, G. D. \& Miles, R. D. 2000. Concepts of Eggshell Quality. In Lechtanski, V. L. (ed.) Inquiry-Based Experiments in Chemistry. New York: Oxford.

[33] Ma, X., Yu, J., and Kennedy, J. F. 2005. Studies on the Properties of Natural Fibers-Reinforced Thermoplastic Starch Composites. Carbohydrate Polymers. 62(1): 19-24.

[34] Lee, C. K., Cho, M. S., Kim, I. H., Lee, Y., and Nam, J. Do. 2010. Preparation and Physical Properties of the Biocomposite, Cellulose Diacetate/Kenaf Fiber Sized with Poly(Vinyl Alcohol). Macromolecular Research. 18(6): 566570.

[35] Kabir, M. M., Wang, H., Cardona, F., and Aravinthan, T. 2011. Effect of Chemical Treatment on the Mechanical 
and Thermal Properties of Hemp Fibre Reinforced Thermoset Sandwich Composites. In Sam Fragomeni, and Srikanth Venkatesan (ed.). Incorporating Sustainable Practice in Mechanics and Structures of Materials. Florida: CRC Press.

[36] Santos, C., Clarke, R. L., Braden, M., Guitian, F., and Davy, K. W. M. 2002. Water Absorption Characteristics of Dental Composites Incorporating Hydroxyapatite Filler. Biomaterials. 23(8): 1897-1904.

[37] Oksman, K., and Clemons, C. 1998. Mechanical Properties and Morphology of Impact Modified Polypropylene-
Wood Flour Composites. Journal of Applied Polymer Science. 67(9): 1503-1513.

[38] Arsène, M.-A., Bilba, K., Savastano Jr, H., and Ghavami, K. 2013. Treatments of Non-Wood Plant Fibres used as Reinforcement in Composite Materials. Materials Research. 16(4): 903-923.

[39] Wang, B., Panigrahi, S., Tabil, L., and Crerar, W. 2007. Pretreatment of Flax Fibers for use in Rotationally Molded Biocomposites. Journal of Reinforced Plastics and Composites. 26(5): 447-463. 